\title{
PENERAPAN PENDEKATAN KONSTEKSTUAL UNTUK MENINGKATKAN KEMAMPUAN BERPIKIR KREATIF SISWA PADA MATERI OPERASI HITUNG CAMPURAN
}

\author{
Baiq Yuni Wahyuningsih \\ Universitas Teknologi Mataram \\ Baiquniq27@gmail.com
}

\begin{abstract}
This research is a Classroom Action Research with 2 (two) cycles which aims to improve students' creative thinking abilities through contextual approaches in mixed count operations material with qualitative approach. Data collection is done through observation, evaluation tools, interviews, documentation, and worksheets. The data analysis technique used in this study is descriptive qualitative Data triangulation is used to test the validity of the data. The data obtained came from three different sources, observers, teachers, and students. This research show most students become active gradually in learning activities. With a contextual approach students are motivated in finding meaning and concepts, observing, analyzing, determining completion strategies and alternatives to find the final result. An increase in students' creative thinking abilities in the aspects of fluency and flexibility from the pre-action stage to the end of the second cycle with a percentage of $25 \%$ to $60 \%$ (fluency) and $17.5 \%$ to $55 \%$ (flexibility).
\end{abstract}

Keywords: Creative thinking, Contextual Learning

\begin{abstract}
Abstrak : Penelitian ini merupakan Penelitian Tindakan Kelas (Classroom Action Research) dengan 2 (dua) siklus yang bertujuan untuk meningkatkan kemampuan berpikir kreatif siswa melalui pendekatan kontekstual dalam materi operasi hitung campuran. Sedangkan, pendekatan penelitian yang digunakan adalah pendekatan kualitatif. Pengumpulan data dilakukan melalui observasi, alat evaluasi, wawancara, dokumentasi, dan LKS. Teknik analisis data yang digunakan dalam penelitian ini adalah deksriptif kualitatif Triangulasi data digunakan untuk menguji keabsahan data. Data yang diperoleh berasal dari tiga sumber yang berbeda, yaitu observer (pengamat), guru, dan siswa. Sebagian besar siswa menjadi aktif secara bertahap dalam kegiatan pembelajaran. Hasil penelitian menunjukkan dengan pendekatan kontekstual siswa termotivasi dalam menemukan makna dan konsep, mengamati, menganalisa, menentukan strategi penyelesaian dan alternatifnya untuk menemukan hasil akhir. Terjadi peningkatan kemampuan berpikir kreatif siswa pada aspek fluency dan flexibility dari tahap pra tindakan hingga akhir siklus II dengan persentase $25 \%$ menjadi $60 \%$ (fluency) dan 17,5\% menjadi 55\% (flexibility).
\end{abstract}

Kata Kunci: Berpikir Kreatif, Pendekatan Kontekstual

Manazhim : Jurnal Manajemen dan Ilmu Pendidikan

Volume 2, Nomor 2, Agustus 2020; 131-142

https://ejournal.stitpn.ac.id/index.php/manazhim 


\section{PENDAHULUAN}

Pada dasarnya pembelajaran matematika berfungsi sebagai sarana untuk mengembangkan kemampuan berpikir kreatif, kritis dan logis. Dengan kata lain, pembelajaran Matematika memiliki sumbangan yang penting untuk perkembangan kemampuan berpikir kreatif dalam diri setiap individu siswa agar menjadi sumber daya manusia yang berkualitas. Oleh karena itu, dalam pembelajaran matematika di sekolah guru harus mampu memahami fungsi-fungsi mata pelajaran matematika sehingga guru dapat menunjukkan hubungan dan keterkitan antara matematika dengan kehidupan nyata ataupun dengan ilmu-ilmu pengetahuan lainnya.

Pembelajaran matematika diberikan sejak tingkat sekolah dasar hingga perguruan tinggi dengan tujuan untuk membekali peserta didik dengan kemampuan berpikir logis, analitis, sistematis, kritis, dan kreatif, serta kemampuan bekerjasama. Kompetensi tersebut diperlukan agar peserta didik dapat memiliki kemampuan memperoleh, mengelola, dan memanfaatkan informasi untuk bertahan hidup pada keadaan yang selalu berubah, tidak pasti, dan kompetitif ${ }^{1}$. Oleh karena itu, dapat dikatakan bahwa pembelajaran matematika memberikan dampak yang sangat penting dalam perkembangan kemampuan berpikir kreatif siswa agar menjadi sumber daya manusia yang berkualitas dan berdaya saing tinggi.

Namun, keterampilan berpikir tidak akan berkembang jika tidak dilatih dan dipergunakan pada setiap kesempatan untuk berpikir. Melatih kemampuan berpikir siswa dapat dimulai dari pemahaman akan disiplin ilmu yang dibangun oleh fakta, konsep, prinsip dan teori-teori yang menuntut berpikir kreatif dalam segala hal. Berdasarkan hal tersebut, maka diperlukan usaha yang dapat menunjang pertumbuhan dan meningkatkan kemampuan berpikir kreatif siswa di antaranya adalah dengan melakukan kegiatan pembelajaran menggunakan starategi/metode yang sesuai dan tepat sasaran. Adzliana Mohd Daud (2012) menyatakan bahwa proses berpikir kreatif merupakan kegiatan berpikir konvergen untuk mendapatkan dan memahami situasi, membuat evaluasi dan mempertimbangkan konsekuensi dari

${ }^{1}$ Depdiknas. (2006). Kurikulum Tingkat Satuan Pendidikan SD/MI. Jakarta: Depdiknas. 
solusi yang diambil ${ }^{2}$. Kreatifitas terintegrasi dalam pengetahuan dan proses sains, sehingga untuk memilikinya diperlukan latihan secara konsisten dalam pembelajaran ${ }^{3}$. Kreatifitas adalah hasil dari proses interaksi antara individu dengan lingkungannya, yang berarti bahwa lingkungan dapat menunjang atau menghambat kreativitas seseorang. Menurut Munandar (2002) kreativitas seseorang tidak muncul begitu saja, tapi perlu ada pemicu untuk memunculkannya. ${ }^{4}$

Beberapa penelitian telah dilakukan terkait dengan pembelajaran untuk meningkatkan kemampuan berpikir kreatif dengan menggunakan pendekatan konstektual, diantaranya yaitu Adang Ruhiyat dan Asep (2016) melakukan penelitian yang bertujuan menelaah pencapaian dan peningkatan kemampuan berpikir kreatif dan disposisi matematik siswa SMP dengan menerapkan pendekatan kontekstual. Hasilnya menunjukkan pencapaian dan peningkatan kemampuan berpikir kreatif matematik dan disposisi matematik siswa dengan pendekatan kontekstual lebih baik daripada siswa yang belajar dengan konvensional ${ }^{5}$. Evaderika dan Abdul Aziz (2017) dalam penelitiannya yang berjudul menumbuh kembangkan kemampuan berpikir kreatif matematis dengan pendekatan contextual teaching and learning (CTL), menyatakan bahwa Siswa yang sudah menggunakan kemampuan berpikir kreatifnya, mereka akan lebih mudah untuk memecahkan masalah matematika maupun menyelesaiakan soalsoal yang bersifat terbuka atau soal yang memiliki banyak alternatif jawaban dan cara. ${ }^{6}$ Maka kreativitas perlu didukung dengan aktivitas-aktivitas yang membuat siswa mengkonstruksi pengetahuan, menemukan ide atau gagasan yang relevan dengan masalah, menggali informasi dengan bertanya, saling sharing, kerjasama, dan membuat model dari masalah matematika melalui pendekatan CTL.

2 Adzliana Mohd Daud, dkk.(2012). Creativity in Science Education. Social and Behavioral Sciences Journal Vol 59

3 Sema Aydin Ceran dkk.(2014). Determination of scientific creativity levels of middle school students and perceptions through their teachers. European Journal of Research on Education, Special Issue: Contemporary Studies in Education

${ }^{4}$ Munandar, S.C.U. (2002). Pengembangan Kreativitas Anak Berbakat. Jakarta : PT Rineka Cipta.

5 Adang R dan Asep Sugandi. (2016). Meningkatkan kemampuan berpikir kreatif serta disposisi matematik siswa smp melalui pendekatan kontekstual Edusentris, Jurnal Ilmu Pendidikan dan Pengajaran, Vol. 3 No. 3 Desember 2016 bal 8

${ }^{6}$ Evaderika A.A dan Abdul Azis S. (2017). Menumbuh Kembangkan Kemampuan Berpikir Kreatif Matematis Dengan Pendekatan Contextual Teaching And Learning. Jurnal Math Educator Nusantara (JMEN) ISSN : 2459-9735 Volume 03 Nomor 02 hal 4 
Saat ini kondisi yang banyak terjadi di sekolah-sekolah adalah kemampuan berpikir kreatif siswa tidak tumbuh secara signifikan, khususnya pada pembelajaran matematika. Matematika menjadi salah satu pelajaran yang kurang dinikmati, karena mempelajari angka dan menghafal banyak rumus. Hal ini berakibat pada kurangnya keinginan dan motivasi untuk belajar matematika karena diberikan label sebagai pelajaran yang sulit. Sehingga pencapaian hasil belajar matermatika dengan standar kompetensi menghitung operasi hitung campuran menunjukkan hasil yang masih jauh dari standar yang ditentukan oleh guru (KKM).

Hasil observasi dilapangan menunjukkan, pada saat mengawali pembelajaran matematika, guru langsung meminta siswa membuka buku Lembar Kerja Siswa (LKS) tanpa memberikan apersepsi dan pertanyaan yang dapat memfasilitasi kemampuan berpikir siswa. Disisi lain materi yang disampaikan guru masih bersifat abstrak dan kurang menggunakan bahan manipulatif untuk mengkonkritkan materi agar lebih mudah dipahami siswa. Guru yang mengajar hanya dengan menyampaikan apa yang ada di buku paket/LKS tidak akan mampu mengakomodasi kemampuan siswa, sebab tidak memberikan kesempatan kepada siswa untuk mengkonstruk pengetahuannya sendiri. Sebagai contoh, dalam pembelajaran dengan materi penjumlahan pecahan, guru memberikan contoh dengan membuat sebuah garis lurus di papan tulis, lalu membagi garis tersebut menjadi dua bagian yang sama besar tanpa menggunakan benda konkrit yang ada di dalam kelas misalnya dengan menggunakan kertas, tapi hal tersebut tidak dilakukan oleh guru dalam mengajarkan pecahan, dan guru kurang mengaitkan pelajaran tersebut dengan kehidupan sehari-hari.

Dalam proses pembelajaran, terlihat guru lebih banyak aktif menjelaskan materi dan tidak membuka kesempatan bagi siswa untuk terlibat dalam aktivitas pembelajaran sehingga kreativitas berpikir kreatif tidak dimunculkan. Hal ini terlihat pada kemampuan siswa menyelesaikan soal-soal latihan yang hanya terfokus pada contoh yang diberikan oleh guru dan tidak mampu ketika diberikan soal dengan gaya yang berbeda sehingga menyebabkan siswa kurang memiliki kemampuan menyelesaikan masalah dengan mencari alternatif lain. Masalah bahwa siswa kurang memiliki kemampuan mencari alternatif lain dapat disebabkan siswa kurang memiliki 
kemampuan fleksibilitas yang merupakan komponen utama kemampuan berpikir kreatif.

Berdasarkan uraian permasalahan diatas, guru dituntut memiliki kreativitas dalam merancang kegiatan pembelajaran yang dapat memfasilitasi kemampuan berpikir kreatif siswa dalam pembelajaran. Salah satu pendekatan pembelajaran yang sesuai dalam pembelajaran matematika yaitu dengan menggunakan pendekatan kontekstual. Dengan pendekatan kontekstual, siswa dapat mengawali pembelajaran dengan pemahaman yang tepat dan dilanjutkan dengan latihan berpikir kreatif melalui stimulus pemberian soal-soal yang bervariasi.

\section{METODE PENELITIAN}

a) Pendekatan dan Jenis Penelitian

Penelitian ini merupakan Penelitian Tindakan Kelas (Classroom Action Research) dengan 2 (dua) siklus yang bertujuan untuk meningkatkan kemampuan berpikir kreatif siswa melalui pendekatan kontekstual dalam materi operasi hitung campuran. Sedangkan, pendekatan penelitian yang digunakan adalah pendekatan kualitatif dimana peneliti ingin mengetahui fenomena dan permasalahan yang terjadi dikelas dan akan menyajikan hasilnya secara deskriptif.

b) Populasi dan Sampel

Populasi dalam penelitian ini adalah siswa-siswi Sekolah Dasar kelas V (lima)yang berjumlah 25 orang siswa. Dengan rincian siswa laki-laki sebanyak 17 orang dan siswa perempuan sebanyak 8 orang siswa. Latar belakang perekonomian siswa di sekolah tersebut adalah menengah ke bawah, dimana sebagian besar pekerjaan orang tua siswa adalah sebagai buruh dan pembuat tahu tempe. Hal tersebut menjadi salah satu faktor yang mempengaruhi prestasi belajar siswa.

c) Teknik Pengumpulan Data

Pengumpulan data dalam penelitian ini dilakukan melalui observasi, alat evaluasi, wawancara, dokumentasi, dan LKS. Observasi dilakukan untuk memperhatikan dan mencatat hal-hal yang terjadi pada saat sebelum dan ketika 
pembelajaran dengan pendekatan kontekstual diadakan di kelas. Selanjutnya alat evaluasi yang digunakan lembar aktivitas siswa selama mengikuti pembelajaran dan lembar refleksi (catatan lapangan) yang digunakan oleh peneliti untuk menemukan kelebihan dan kekurangan yang terjadi dilapangan sebagai bahan pertimbangan untuk pembelajaran selanjutnya. Wawancara dan dokumentasi dilakukan untuk memperkuat data penelitian yang diperoleh.

d) Teknik Analisis Data

Teknik analisis data yang digunakan dalam penelitian ini adalah deksriptif kualitatif Triangulasi data digunakan untuk menguji keabsahan data. Data yang diperoleh berasal dari tiga sumber yang berbeda, yaitu pengamat, guru, dan siswa. Data tersebut terbagi atas data kualitatif yang diperoleh dengan cara reduksi data dari penyederhanaan instrumen pengumpulan data berupa: observasi deskriptif dari pengamat, catatan lapangan oleh peneliti, dan wawancara dengan siswa. Sedangkan, data kuantitatif diperoleh melalui instrumen penelitian berupa: rubrik dari hasil Lembar Kerja Siswa (LKS).

\section{e) Rancangan Penelitian}

Secara garis besar, menyatakan penelitian tindakan kelas (PTK) terdiri atas beberapa siklus atau pengulangan dari siklus. Dimana setiap siklus terdiri dari empat tahapan, yaitu: 1) Tahap Pengembangan Plan (perencanaan), 2) Tahap Act (tindakan),

3) Tahap Observe (pengamatan), dan 4) Tahap Reflect (refleksi) ${ }^{7}$. Keempat tahapan tersebut merupakan unsur yang membentuk sebuah siklus, yaitu satu putaran kegiatan beruntun. Adapun rangkain siklus-siklus tersebut dapat dirincikan sebagai berikut :

\section{Tahap Plan (perencanaan)}

Perencanaan dalam penelitian tindakan ini akan menekankan pada sifat-sifat strategic yang dapat mnjawab tantangan yang muncul dalam perubahan sosial dan mengenal rintangan yang sbenarnya. Di dalam tahap perencanaan, peneliti juga perlu menjelaskan persiapan-persiapan pelaksanaan penelitian, seperti rencana pelaksanaan pembelajaran dan instrumen pengamatan (observasi).

${ }^{7}$ Sukardi. (2014). Metodologi penelitian pendidikankompetensi dan praktiknya. Jakarta: Bumi Aksara 


\section{Tahap Act (tindakan)}

Pada tahap tindakan, dilakukan kegiatan implementasi atau penerapan perencanaan tindakan. Di dalam kegiatan implementasi ini, maka guru (peneliti) harus mentaati perencanaan yang telah disusun. Tindakan yang baik adalah tindakan yang memuat 3 (tiga) unsure penting, yaitu the improvement of practice, the improvement of understanding individualy and collaboratively, and improvement of the situation in which the action takes place. Kegiatan ini penting karena tujuan penelitian tindakan kelas adalah untuk memperbaiki proses pembelajaran.

\section{Tahap Observe (pengamatan)}

Observasi yang baik adaah observasi yang fleksibel dan terbuka untuk dapat mencatat gejala yang muncul baik yang diharapkan atau yang tidak diharapkan. Pada tahap pengamatan terdapat dua kegiatan yang akan diamati, yaitu kegiatan belajar siswa dan kegiatan pembelajaran. Pengamatan terhadap proses belajar siswa dapat dilakukan sendiri oleh peneliti sambil melaksanakan pembelajaran, Sedangkan pengamatan terhadap proses pembelajaran, peneliti dapat meminta bantuan kepada teman sejawat yang bertindak sebagai observer untuk melakukan pengamatan. observer melakukan pengamatan pembelajaran berdasarkan instrumen yang telah disusun oleh peneliti. Hasil pengamatan dari observer nantinya akan bermanfaat atau akan digunakan peneliti sebagai bahan refleksi untuk perbaikan pembelajaran berikutnya.

\section{Tahap Reflect (refleksi)}

Tahapan refleksi dilakukan untuk melakukan peninjauan dan membuat gambaran dari situasi proses penelitian yang dilakukan serta untuk melihat hambatan yang muncul dalam tindakan dan kemungkinan lain yang muncul selama proses penelitian. Kegiatan refleksi dilaksanakan ketika observer sudah selesai melakukan pengamatan terhadap peneliti dalam melaksanakan pembelajaran. Kegiatan ini dapat berupa diskusi hasil pengamatan yang dilakukan oleh observer dengan guru pelaksana (peneliti). Hasil refleksi dapat digunakan sebagai bahan pertimbangan dalam merancang siklus berikutnya. 


\section{HASIL DAN PEMBAHASAN}

\section{Siklus I}

Berdasarkan pelaksanaan siklus I, diperoleh hasil observasi aktivitas siswa antara lain ditinjau dari hasil pengerjaan LKS siswa belum siap untuk menerima pelajaran dan siswa kurang aktif dalam bertanya, mengemukakan pendapat dan menjawab pertanyaan. Sedangkan hasil observasi untuk aktivitas guru pada siklus I masih menunjukkan banyak kekurangan seperti guru tidak menjelaskan penggunaan dari alat peraga yang digunakan, guru kurang aktif mengembangkan pertanyaan dalam LKS dan guru kurang memandu jalannya diskusi kelompok untuk memacu siswa memunculkan kemampuan berpikir kreatifnya.

Soal yang dicantumkan dalam evaluasi berbentuk uraian sebanyak 5 soal dan setiap soal mewakili aspek kemampuan berpikir kreatif yang diukur (Evans, 1991) yaitu: 1) Aspek fluency meliputi kelancaran atau kefasihan. Aspek ini menilai kemampuan membangun banyak ide secara mudah. Makin banyak ide yang diperoleh, makin besar peluang untuk mendapatkan ide yang bagus. Terdapat 3 (tiga) jenis fuency, diantaranya Ideational fuency (kecepatan membangun ide berdasarkan kuantitas, associational fuency (menyelesaikan keterkaitan, dapat juga diterapkan dalam mengkonstruksi analogi, dan expressional fluency (kemampuan untuk mengkonstruksi kalimat); 2) Aspek flexibility meliputi keluwean atau kelenturan. Aspek ini menilai kemampuan membangun ide yang beragam. Dalam pemecahan masalah keluwesan terkait dengan kemampuan untuk mencoba berbagai pendekatan dalam menyelesaikan suatu masalah. Terdapat 2 (dua) jenis flexibility yaitu spontaneous flexibility (kemampuan untuk beralih ke jawaban lain tanpa harus diarahkan) dan adaptifflexibility (jawaban yang orisinil).

Berdasarkan data yang diperoleh dari perhitungan kemampuan berpikir kreatif siswa dari hasil jawaban evaluasi siswa dari kemampuan fuency dan flexibility yang diukur, diperoleh gambaran mengenai persentase penguasaan kedua aspek berpikir kreatif siswa yang diperoleh pada siklus I (pertemuan pertama dan kedua) sebesar $40 \%$ untuk aspek fluency dan 27,5\% aspek flexibility. Hal ini menunjukkan terjadi sedikit peningkatan kemampuan berpikir kreatif siswa sebelum diberikan tindakan dengan setelah dilakukan siklus I. Meskipun belum menunjukkan perubahan 
yang signifikan menjadi lebih tinggi, namun pada siklus I siswa mulai merasa antusias dalam proses belajar dan menikmati arahan dan bimbingan guru untuk memunculkan berpikir kreatifnya. Peningkatan aspek fluency diperoleh sebesar 15\% (dari 25\% menjadi 40\%), sedangkan flexibility meningkat sebesar 10\% (dari 17,5\% menjadi 27,5 $\%$.

Berdasarkan kegiatan pembelajaran siklus I dari pertemuan pertama dan kedua, dilakukan analisis dan refleksi terhadap dua aspek kemampuan berpikir kreatif yang menjadi catatan lapangan untuk mengetahui keberhasilan ataupun kekurangan terhadap pembelajaran yang telah dilakukan. Bebeberapa catatan lapangan yang diperoleh, di antaranya:

a. Penyampaian materi belum banyak memberikan keterlibatan pada siswa untuk menemukan dan membangun konsep pemahamannya sendiri, agar dapat melatih dan mengembangkan kemampuan berpikir siswa yang dihubungkan dengan kehidupan yang dialami oleh siswa sehari-hari dengan menggunakan kalimat yang mudah di pahami.

b. Penggunaan kalimat dalam penulisan soal harus disesuikan dengan kondisi siswa yaitu dengan kalimat yang sederhana dan mudah dipahami agar tidak ada penafsiran/kebingungan yang dialami siswa

c. Membuka kesempatan bagi setiap siswa untuk berbicara dan berdiskusi dalam kelompok

\section{Siklus II}

Pelaksanaan siklus II dilakukan dalam 2x pertemuan. Kegiatan pembelajaran Siklus II dirancang berdasarkan catatan lapangan dari siklus I yang memuat kelebihan dan kekurangan yang akan diperbaiki dalam pembelajaran selanjutnya. Berdasarkan hasil observasi aktivitas guru dan siswa menunjukkan terdapat sebagian siswa yang belum aktif dalam pembelajaran sehingga kesulitan untuk dapat memunculkan kemampuan berpikir kreatifnya. Hal ini dikarenakan kurangnya motivasi dalam diri siswa, sehingga siswa tidak berani dalam mengemukakan ide atau gagasan yang dimiliki meskipun sudah mengetahui jawabannya. Nilai rata-rata hasil pengerjaan LKS pada siklus II menunjukkan adanya peningkatan kreativitas siswa yang diperoleh berdasarkan hasil jawaban soal tentang penjumlahan dan pengurangan pecahan yang 
berpedoman pada kisi-kisi alat kreativitas pada LKS. Aspek berpikir kreatif yang paling menonjol yaitu aspek fluency dengan persentase peningkatan pada Siklus II sekitar $20 \%$ menjadi 60\% sedangkan aspek flexibility menunjukkan adanya peningkatan sebesar $27.5 \%$ dari siklus sebelumnya menajdi 55\%. Interpretasi peningkatan kemampuan berpikir kreatif pada siklus I dan II dapat dilihat dalam diagram berikut:

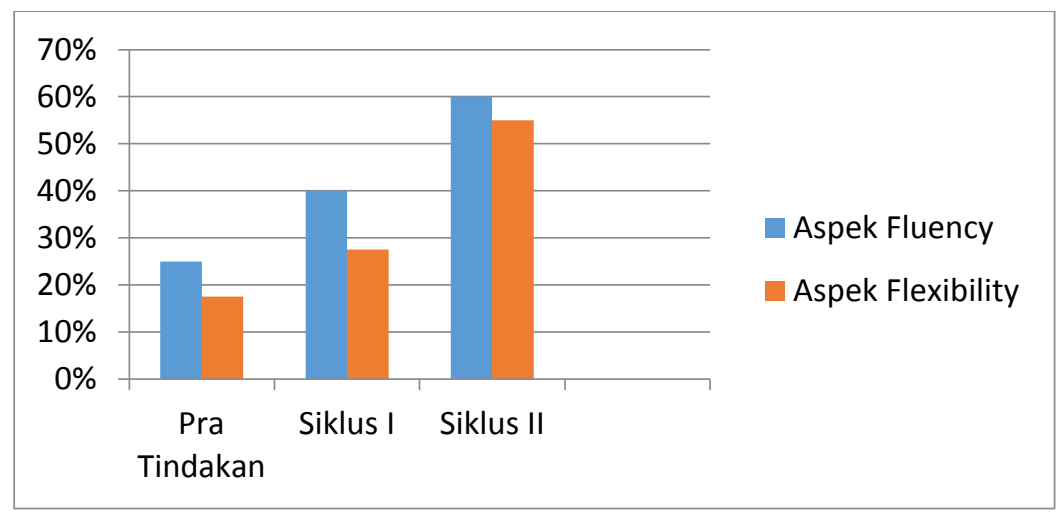

\section{Peningatan Kemampuan Berpikir Kreatif Siswa}

Berdasarkan diagram terlihat bahwa kemampuan berpikir kreatif siswa semakin meningkat dari fase para tindakan hingga ke siklus II. Pada siklus I siswa mulai diarahkan untuk dapat belajar memahami konsep operasi hitung penjumlahan dan penguranan melalui pendekatan kontekstual yaitu dengan memanfaatkan bendabenda konkrit dan mengaitkan dengan permasalahan yang kerap dialami siswa dalam kehidupan sehari-hari. Meskipun merasa kesulitasn diawal, siswa terlihat bersemangat dan termotivasi dalam melakukan pengamatan, menganalisa, menentukan strategi, memprediksi hingga menentukan hasil akhir. Selain dengan pendekatan kontekstual, siswa diberikan kesempatan untuk belajar dan diskusi bersama kelompok yang anggotanya heterogen berdasarkan tingkat kemampuan yang berbeda. Dalam proses diskusi, siswa diberikan kesempatan untuk melakukan interaksi dan tanya jawab antar anggota, melihat alternatif penyelesaian masaah dari setiap anggota, serta menghubungkan pendapat antar anggota untuk bersama-sama menarik kesimpulan.

Selain itu, dari hasil wawancara beberapa siswa menyatakan rasa senang dan termotivasi untuk belajar dengan menggunakan pendekatan kontesktual tersebut. Karena selama ini, dalam belajar matematika sering kali siswa diajarkan secara 
konvensional, tanpa memanfatkan bahan-bahan manipulatif/benda konkrit dan hanya terfokus pada penyampaian materi dan penyelesaian soal latihan tanpa pemahaman konsep dan maknya yang baik. Oleh karena itu, untuk membantu siswa dalam melatih kemampuan berpikir dalam setiap pembelajaran khususnya matematika, diperlukan perencanaan pembelajaran dengan pendekatan yang disesuaikan dengan karakteristik siswa serta tujuan pembelajaran yang ingin dicapai. Pembelajaran ini dapat merangsang kemampuan berpikir siswa sehingga siswa dapat berpikir lebih kreatif dalam menghadapi dan menyelesiakan masalah melalui setiap aktivitas nyata yang dilakukan mereka secara langsung.

Sebagaimana yang dikatakan oleh ${ }^{8}$ Lubard (2005) berpikir kreatif membantu anak menjadi berhasil guna jika kita tidak bersama mereka. Belajar kreatif adalah aspek penting dalam upaya kita membantu siswa agar mereka lebihmampu menangani dan mengarahkan belajar bagi mereka sendiri. Selain itu, Winarti menyatakan bahwa dalam pendidikan perlu ditekankan kreativitas dalam rangka pengembangan potensi peserta didik. Pengembangan tersebut perlu dilatihkan kepada peserta didik melalui berbagai kegiatan pembelajaran yang memacu kemampuan berpikir kreatif.

\section{KESIMPULAN}

Berdasarkan pelaksanaan penelitian tindakan kelas yang dilakukan dalam 2 (dua) siklus, didapatkan kesimpulan, antara lain:

1. Sebagian besar siswa menjadi aktif secara bertahap dalam kegiatan pembelajaran. Dengan pendekatan kontekstual siswa termotivasi dalam menemukan makna dan konsep, mengamati, menganalisa, menentukan strategi penyelesaian dan alternatifnya untuk menemukan hasil akhir.

2. Terjadi peningkatan kemampuan berpikir kreatif siswa pada aspek fluency dan flexibility dari tahap pra tindakan hingga akhir siklus II dengan persentase 25\% menjadi 60\% (fluency) dan 17,5\% menjadi 55\% (flexibility).

\footnotetext{
9 Winarti. (2015). Contextual teaching and learning (ctl) untuk Meningkatkan kemampuan berpikir kreatif siswa. JPFK, Vol. 1 No. 1, Maret 2015 hal 7
} 
3. Pada Aspek Fluency, siswa sudah menunjukkan banyak keaktifan dalam belajar seperti mampu berpikir cepat untuk menyelesaikan masalah, mengungkapkan banyak jawaban dan gagasan atau pertanyaan serta memberikan saran untuk anggota kelompok yang lain.

4. Pada aspek Flexibility, dalam menyelesaikan masalah bersama kelompok, siswa mampu untuk saling menanggapi gagasan alternative penyelesaian yang dikemukakan oleh anggota yang lain dan bersama-sama menentukan strategi penyelesaian yang paling tepat melalui diskusi.

\section{DAFTAR PUSTAKA}

Adzliana Mohd Daud, dkk.(2012). Creativity in Science Education. Social and Behavioral Sciences Journal Vol 59. Page 467 - 474.

Adang R dan Asep Sugandi. (2016). Meningkatkan kemampuan berpikir kreatif serta disposisi matematik siswa smp melalui pendekatan kontekstual Edusentris, Jurnal Ilmu Pendidikan dan Pengajaran, Vol. 3 No. 3 Desember 2016

Depdiknas. (2006). Kurikulum Tingkat Satuan Pendidikan SD/MI. Jakarta: Depdiknas.

Evaderika A.A, Abdul Azis S. (2017). Menumbuh Kembangkan Kemampuan Berpikir Kreatif Matematis Dengan Pendekatan Contextual Teaching And Learning. Jurnal Math Educator Nusantara (JMEN) ISSN : 2459-9735 Volume 03 Nomor 02 Halaman 59 - 145.

Munandar, S.C.U. (2002). Pengembangan Kreativitas Anak Berbakat. Jakarta : PT Rineka Cipta.

Sema Aydin Ceran dkk.(2014). Determination of scientific creativity levels of middle school students and perceptions through their teachers. European Journal of Research on Education, Special Issue: Contemporary Studies in Education, page 47-53

Sukardi. (2014). Metodologi penelitian pendidikankompetensi dan praktiknya. Jakarta: Bumi Aksara

Winarti. (2015). Contextual teaching and learning (ctl) untuk Meningkatkan kemampuan berpikir kreatif siswa. JPFK, Vol. 1 No. 1, Maret 2015 : 1-8 